\title{
Vapaa sivistystyö valtion budjetissa
}

Joensuun konferenssin jälkeen aikuiskoulutus on "hyväksytty" niiden aihepiirien joukkoon, joita tiedotusvälineet käsittelevät ahkerasti ja joista myös poliitikot eri puolueissa tuntuvat kiinnostuneen. Opetusministeriön johdolla aikuiskoulutuksen suunnittelu- ja kehittämistyötä on kuitenkin tehty tiiviisti jo pitkään. Pieniä ja vähän isompiakin osauudistuksia on toteutettu siitä esitystulvasta, jota eri komiteat ja toimikunnat ovat laatineet.

Vapaan sivistystyön kohdalla kansanopistojen lainsäädännön uudistus 1980-luvun puolivälissä oli merkittävä. Ammatillisen aikuiskoulutuksen rahoitukseen ja kehittämiseen liittyvät periaatepäätökset ja niiden pohjalta tehtävät uudistukset saattavat merkitä suuria muutoksia ammatillisessa aikuiskoulutuksessa. Myös vapaan sivistystyön eri työmuodoissa odotetaan lainsäädännön kehittämistä, mikä vaikuttanee myös valtionrahoitukseen.

Kun seuraavassa tarkastelen joitakin vapaan sivistystyön budjettilukuja, voidaan edellä esitettyyn liittyen todeta, että valtion talousarvioon tämä aikuiskoulutuksen saama yleinen huomio ja sen merkityksen korostaminen ei ole jättänyt ainakaan vielä merkkejä. Budjetti toteuttaa pienten askelten linjaansa. Eri vuosien vertailua haittaa budjettirakenteessa silloin tällöin tehdyt muutokset. Esim: vuonna 1984 aikuiskoulutuksen osuus näyttää pienentyneen
$10 \%$ :sta $8 \%$ :iin opetusministeriön pääluokasta. Muutos aiheutui kuitenkin työllisyyskoulutuksen koulutus- ja erityistuen siirtämisestä työvoimaministeriön pääluokkaan, joten se ei ollut todellinen. Myös v. 1988 nk. maksullisen palvelutoiminnan periaatteen johdosta aikuiskoulutuksen määrärahoja siirrettiin sosiaali- ja terveysministeriön pääluokkaan.

Tutkittaessa valtion tulo- ja menoarviossa aikuiskoulutukseen osoitettuja varoja, joudutaan myös määrittelyvaikeuksiin. Mikä on aikuiskoulutusta? Poimitaanko aikuiskoulutukseen liittyvät menot vain opetusministeriön pääluokasta ja miten ne voidaan poimia sieltäkään luotettavasti, kun on oppilaitosryhmiä, joissa annetaan sekä nuorisoasteen opetusta että aikuiskoulutusta. Seuraavassa vertailussa tämä ongelma on ohitettu käyttämällä tulo- ja menoarvion yleisperustelujen jaottelua. Siinä aikuiskoulutuksen keskeisen osan muodostavat yhteiskunnallinen sivistystyö ja ammatillinen kurssitoiminta.

Koulutuskustannuksia kokonaisuudessa tarkastelu ei siis kata, vaan esityksessä on keskitytty valtion antamaan tukeen, joka on erilainen eri koulutusmuodoille. Vuosittain oppilaitoksilta kerätään tiedot taloudesta ja suoritteista nk. koulutuskustannusrekisteriin. Tätä rekisteriä ei ole ollut käytettävissä esitystä laadittaessa.

Taulukko 1: Opetusministeriön hallinnonalan menojen kehitys valtion tulo- ja menoarviossa 1986-88

$\begin{array}{lll}1986 & 1987 & 1988 \\ \text { milj. } & \text { milj. } & \text { milj. }\end{array}$

\begin{tabular}{lccc}
\hline Budjetin loppusumma & 101428 & 102628 & 113816 \\
Opm:n pääluokka & 16090 & 17664 & 19483 \\
Opm:n osuus budjetin & & & 17.1 \\
loppusummasta \% & 15.9 & 17.2. & \\
$\quad$ Yleissiv. opetus & & 39.8 & 39.3. \\
opm:n pääluokasta \% & 40.8. & 20.6 & 14.9 \\
Ammattiopetus \% & 19.9 & 7.5 & 7.4 \\
$\quad$ Korkeakouluopetus \% & 14.1 & & 1.3 \\
$\quad$ Aikuiskoulutus \% & 7.9 & 1.4 & \\
Aikuiskoulutus budjetin & 1.2 & &
\end{tabular}


Opetusministeriön hallinnonalan lisäys oli 1988 budjetissa $10 \%$. Ammattiopetus ja korkeakoulut saivat osalleen suurimman kasvun (14\%), aikuiskoulutuksen lisäys oli 4 \% (1987 1397 milj. ja 19881450 milj.). Aikuiskoulutuksen absoluuttinen markkamäärä siis kasvoi jonkin verran, vaikka sen suhteellinen osuus opetusministeriön pääluokassa pieneni. Muutaman vuoden aikavälillä voidaan todeta, että v. 1984 aikuiskoulutuksen osuus opm:n mää- rärahoista oli 8 \%, v. $19857.2 \%$ sekä v. 1988 $7.4 \%$. Koko talousarviosta aikuiskoulutuksen osuus vaihtelee samalla aikavälillä $1.2-1.4 \%$ välillä.

Valtion talousarvion perusteella ei siis aikuiskoulutus ainakaan toistaiseksi ole ollut paiǹopistealue yhteiskuntaa kehitettäessä, vaan määrärahojen suhteellinen osuus on ollut verraten vakaa.

Taulukko 2: Yhteiskunnallisen sivistystyön määrärahat valtion tulo- ja menoarviossa 1986—88

\begin{tabular}{lccr} 
Määrärahan kohde & $\begin{array}{c}1986 \\
\text { milj. }\end{array}$ & $\begin{array}{c}1987 \\
\text { milj. }\end{array}$ & $\begin{array}{l}1988 \\
\text { milj. }\end{array}$ \\
\hline Kansanopistot & 170 & 178 & 201 \\
Kansalais- ja työväenopistot & 270 & 284 & 301 \\
Opintokeskukset & 50 & 54 & 56 \\
Sivistysjärjestöt & 12 & 13 & 14 \\
Muut & 7 & 537 & 580 \\
Yhteensä & 509 & 38.4 & 40.0 \\
Yhteiskunnallisen sivistystyön osuus & & &
\end{tabular}

Taulukko 3: Vapaan sivistystyön opiskelijat 1984-86

\begin{tabular}{|c|c|c|c|}
\hline Työvuosi & $1984-85$ & $1985-86$ & $1986-87$ \\
\hline Kansalais- ja työväenopistot & 624715 & 623829 & 629039 \\
\hline $\begin{array}{l}\text { Kansanopistot } \\
\text { perusoppijaksot } \\
\text { kurssit }\end{array}$ & $\begin{array}{r}6405 \\
41624\end{array}$ & $\begin{array}{r}6244 \\
44478\end{array}$ & $\begin{array}{r}5971 \\
\text { n. } 45000\end{array}$ \\
\hline Kalenterivuosi & 1984 & 1985 & 1986 \\
\hline $\begin{array}{l}\text { Opintokeskukset } \\
\text { opintokerhot } \\
\text { kurssit } \\
\text { ohjaajakoulutus } \\
\text { luennot }\end{array}$ & $\begin{array}{rr}235 & 468 \\
230 & 931 \\
20 & 297 \\
246 & 454\end{array}$ & $\begin{array}{rr}210 & 149 \\
225 & 086 \\
19 & 113 \\
212 & 747\end{array}$ & $\begin{array}{rl}179 & 290 \\
214 & 321 \\
18916 \\
259 & 505\end{array}$ \\
\hline
\end{tabular}

Vapaan sivistystyön volyymin tarkastelua haittaa erilainen tilastointitapa. Kansanopistojen valtionapujärjestelmän muututtua vuoden 1985 alusta, tuli siellä ensiarvoisen tärkeäksi laskennan perusteeksi opiskelijaviikko eli yhden opiskelijan vähintään 25 opetustuntia kestävä opiskelu. Koko maata koskevia tuntimääriä ja opiskelijamääriä ei ole enää systemaattisesti saatavissa, on vain opiskelijaviikkoja.

Kansalais- ja työväenopistojen opiskelijamäärissä ei ole tapahtunut oleellisia muutoksia. Kansanopistojen toiminnalle kurssit näyttävät tulevan yhä merkityksellisemmiksi, sillä vielä viitisen vuotta kurssien opiskelijamäärät olivat noin 10000 nykyistä pienemmät. Perusoppijakson opiskelijamäärän laskusta ei voi vielä vetää pitkälle meneviä johtopäätöksiä, lasku voi olla satunnainenkin. Opintokerhojen osallistujien määrän laskua voidaan pitää hätkähdyttävänä eikä toistaiseksi ole selvitetty, mistä näin voimakas määrällinen väheneminen on aiheutunut. Koko vapaa sivistystyön toiminnan volyymi on noin 1.3 miljoonaa opiskelijaa, mikä tietysti merkitsee vain opintojensa aloittaneiden määrää sisältäen myös päällekkäisyyttä. Huomattava on myös se,että mukana on kovin erilaisia opiskelijoita: sekä kertatilaisuuksiin osallistuvia että koko työvuoden kansanopistossa puurtavia. 
Taulukko 4: Toiminnan volyymi ja valtionosuus

Kansanopistot (90)

\begin{tabular}{ccc}
$\begin{array}{c}\text { opiskelijaviikkoja } \\
1986-87\end{array}$ & $\begin{array}{c}\text { opetustunteja } \\
1986-87\end{array}$ & \multicolumn{2}{c}{$\begin{array}{c}\text { valtionapu } \\
1987\end{array}$} \\
\hline 254715 & 585844 & 178 milj.
\end{tabular}

Kansalais-

ja työväenopistot (278)

\begin{tabular}{ccc}
$\begin{array}{c}\text { opiskelijoita } \\
1986-87\end{array}$ & $\begin{array}{c}\text { opetustunteja } \\
1986-87\end{array}$ & $\begin{array}{c}\text { valtionosuus } \\
1987\end{array}$ \\
\hline 629039 & 2023671 & 284 milj.
\end{tabular}

Opintokeskukset (10)

\begin{tabular}{ccr}
$\begin{array}{c}\text { opiskelijoita } \\
1986\end{array}$ & $\begin{array}{c}\text { opetustunteja } \\
1986\end{array}$ & \multicolumn{1}{c}{$\begin{array}{c}\text { valtionapu } \\
1986\end{array}$} \\
\hline & & \\
179290 & 408166 & 7.5 milj. \\
214321 & 103829 & 18.0 milj \\
18916 & 9524 & 2.6 milj. \\
259505 & 9988 & 1.9 milj.
\end{tabular}

opintokerhot

kurssit

ohjaajakoulutus

luennot
103829

9988
2.6 milj.

1.9 milj.
Opetustunti on viime vuosina vakiintunut toiminnan laajuuden keskeiseksi mittariksi. Sillä myös säädellään toiminnan kasvua eri työmuodoissa. Kansanopistoissa suoriteperusteisen valtionosuuden perustana käytetty opiskelijaviikko merkitsee yhden opiskelijan viikon opiskelua. Opetuksen enimmäismäärä opiskelijaviikkoa kohti saa olla opiston koosta riippuen 2.2-2.4. Yllä olevassa taulukossa kansanopistojen opetustuntien määrä on saatu kertomalla opiskelijaviikot 2.3:lla. Kansanopistojen valtionapu opiskelijaviikkoa kohti saadaan jakamalla kokonaisavustus opiskelijaviikoilla ja vastaavasti opetustuntia kohti jakamalla opetustuntien määrällä. On huomattava, että lukuun vaikuttaa opistojen internaattiluonne. Opiskelijaviikkoa kohti valtionrahoitus on $698.8 \mathrm{mk}$ ja opetustuntia kohti $303.8 \mathrm{mk}$. Laskelmasta puuttuvat erilliset rakennusavustukset sekä opiskelijoille myönnettävä valtiontuki. Kansanopistojen tuloista 1986 valtioanapu oli
$41.5 \%$, kurssi- yms. maksut $28.1 \%$, kuntien ja yksityisten avustukset $5.7 \%$, avustukset sijoitusmenoihin sekä lainat $14.9 \%$, muut tulot $9.8 \%$. Valtionosuus käyttömenoihin oli $54.0 \%$.

Kansalais- ja työväenopistojen valtionosuudeksi annettua opetustuntia kohti saadaan 136.2 mk. Valtionosuus käyttömenoihin oli keskimäärin $63.7 \%$. Koska opistoista $90 \%$ on kuntien omistamia, ne myös vastaavat pääosasta niitä kustannuksia, joita valtionosuus ei kata. Opintomaksujen yms. osuus tuloista on vain $3-4 \%$.

Opintokerhojen tuntimäärä on tässä myös laskennallinen; kerhomäärä on kerrottu 22:lla. Opintokerhojen saama avustus oli tavallisten kerhojen osalta v. $1986270 \mathrm{mk}$ ja v. 1987280 mk. Tasonsa perusteella korotettua avustusta saivat kerhot v. $1986670 \mathrm{mk}$ ja v. $1987700 \mathrm{mk}$. Opintokerhojen määrän lasku on aiheuttanut sellaisen harvinaisen tilanteen, että kerhomäärärahaa on jäänyt käyttämättä (v. 1987 opinto-

Taulukko 5: Opintokeskusten yleismenojen jako eri toimintamuodoille 1986

\begin{tabular}{lllll}
\hline Toimintamuoto & valtionapu & $\%$ & yleismenoihin & toimintamuodoille \\
& toiminta- & & tulevan valt. & jyvitetty valtion- \\
& muodoille & & avun jako & apu
\end{tabular}

\begin{tabular}{lrrrr}
\hline Opintokerho & 7.450000 & 25 & 4.907500 & 12.357500 \\
Kurssit & 18.000000 & 60 & 11.778000 & 29.778000 \\
Ohjaajakoulutus & 2.600000 & 9 & 1.766700 & 4.366700 \\
Luennot & 1.900000 & 6 & 1.177800 & 3.077800 \\
\hline Yhteensä & 29.950000 & 100 & 19.630000 & 49.560000 \\
\hline
\end{tabular}

Yleismenot $\quad 19.630000$

Valtionapu yht. $\quad 49.580000$ 
kerhojen 7.5 milj. määrärahasta käytettiin kerhotyöhön vain n. 4.5 milj).

Opintokeskukset saavat valtionapua yleismenoihinsa sekä erikseen kuhunkin toimintamuotoon. Taulukossa 5 opintokeskusten saama tuki yleismenoihin on jyvitetty toimintamuodoille niille myönnetyn valtionavun määrän suhteessa.

Kun jyvitetty valtionapu jaetaan eri toimintamuotojen opetustunneille, saadaan valtion tueksi opintokerhotunnille $30.3 \mathrm{mk}$, kurssitunnille $286.8 \mathrm{mk}$ sekä ohjaajakoulutustunnille 458.5 mk ja luentotunnille $308.1 \mathrm{mk}$.

Ohjaajakoulutuksessa valtio osallistuu myös opiskelijain majoitus- ja matkakustannuksiin. Myös kurssien osallistujille voidaan maksaa matkakorvauksia tietyin ehdoin. Luentotoiminnassa taas asiantuntijapalkkiot ovat muuta opetustoimintaa kalliimmat. Halvinta toimintaa on opintokerho.

Opintokeskusten käyttömenoista valtionapu kattoi v. 198667 \%, toimitus- ja opintomaksujen osuus oli $19 \%$, taustajärjestöt tukivat $9 \%$.

\section{Yhteenvetoa}

Edellä on tarkasteltu vain valtion budjetissa ilmenevää yhteiskunnan tahtoa tukea aikuiskoulutusta ja erityisesti vapaata sivistystyötä. Vertailua muihin koulutusmuotoihin ei ole tehty. Selvitystä tehtäessä nousi esiin kysymys tilastoinnista ja seurantajärjestelmistä, vaikka valtion keskushallinnolla lieneekin käytettävissään enemmän tietolähteitä kuin minulla artikkelia kirjoittaessani. Esimerkiksi: tietääkö joku, kuinka paljon yhteiskunta tosiasiassa käyttää aikuiskoulutukseen? Vuoden 1988 budjetissa ilmaistu 1450 milj. mk ei ole koko totuus, sillä opetusministeriön pääluokassa ei ole suinkaan kaikki koulutusmäärärahat, vaan niitä on myös muiden pääluokkien kohdalla. Myös opetusministeriön pääluokassa on momentteja, jotka sisältävät osittain aikuiskoulutusmäärärahoja, mutta niitä ei ole erotettu muiden koulutusasteiden määrärahoista. Tulevaisuudessa opetusministeriön osuus ammatillisen aikuiskoulutuksen rahoituksesta tulee pienenemään, koska aikuiskoulutusmäärärahoja on yhä enemmän muiden ministeriöiden kohdalla.

Verrattaessa vapaan sivistystyön eri työmuotojen kustannuksia ja niiden saamaa tukea, täytyy muistaa toimintamuotojen erilaisuus.
Kustannukset muodostuvat suorien opetuspalkkioiden lisäksi hyvin eri tavoin. Jos tarkastellaan esimerkiksi kansanopistojen menoja toiminnoittain, havaitaan, että v. 1986 opetustoiminta muodosti menoista $23.7 \%$. Jos siihen lisätään hallinto, saadaan tulokseksi $36.5 \%$. Sen sijaan kiinteistö- ja sijoitusmenot yhdessä ovat peräti $46.9 \%$. Kansalais- ja työväenopistoissa opetus muodostaa $57.8 \%$ menoista ja yhdessä hallinnon kanssa $80.3 \%$. Kiinteistöjen hoito ja sijoitusmenot ovat yhteensä $19.1 \%$.

Kun opettajakustannukset ovat kalliimpaa luento-opetusta lukuunottamatta noin 100 markan vaiheilla opetustuntia kohti, voidaan todeta, että niissä työmuodoissa, joissa yleensä käytetään opettajaa, valtionosuus kattaa opetuspalkkiot ja osittain muitakin menoryhmiä. Valtion tuki oppituntia kohti vaihtelee 30 markasta (opintokerho) 458 markkaan (ohjaajakoulutus). Kustannuksia tarkasteltaessa on kuitenkin muistettava, että mikäli näiden työmuotojen edellytetään järjestävän täysipainoisia koulutustilaisuuksia aikuisille, ei enää riitä opettaja ja karttakeppi. Ei riitä, että jotakin kerran onnistuneesti toteutettua kurssia tai koulutusohjelmaa junnataan samanlaisena vuodesta toiseen. Täysipainoista opetusta ei järjestetä, ellei huolehdita esim. opettajien ja kouluttajien täydennyskoulutuksesta ja opetusohjelmien jatkuvasta kehittämisestä ja muokkaamisesta. Tämä on edellytys, halutaan sitten painottaa vapaan sivistystyön perinteisiä arvoja tai mennä mukaan "hyötytavoitteiseen" opetukseen.

\section{Lähteet}

Sirén, Hannu, Näkökulma aikuiskasvatuksen kustannuksiin. Aikuiskasvatus 1/1985.

Tilastotietoja kansanopistoista, kansalais- ja työväenopistoista ja musiikkioppilaitoksista työvuonna 1986-87 sekä opintokeskuksista ja urheiluopistoista vuonna 1986. Tutkimuksia ja selvityksiä 2/ 1987. Kouluhallitus.

Uuden kansanopistolainsäädännön toimivuuden seuranta. Lausunto 1986. Kouluhallitus.

Valtion tulo- ja menoarvioesitykset 1986, 1987 ja 1988.

Yhteenveto vapaan sivistystyön oppilaitosten kustannuksista vuosilta 1984-86. Kouluhallitus. Suunnittelutoimisto.

Yrjölä, Pentti, Aikuiskasvatus valtion budjetissa ja koulutuskustannukset vapaassa sivistystyössä. Aikuiskasvatus 4/1984 